\title{
Rainfall Characteristics in Ahmednagar District of Maharashtra State
}

\author{
'Dr. Vasudev. S. Salunke ${ }^{1}$, Pramila. P. Zaware ${ }^{2}$
}

${ }^{1}$ Department of Geography, K.J.Somaiya College Kopargaon, S. P. Pune University, Pune, Maharashtra, India

${ }^{2}$ Research Scholar, Babasaheb Ambedkar Marathwada University, Aurangabad, Maharashtra, India

"Corresponding Author : vasusalunke@yahoo.co.in

\begin{abstract}
Article Info

Volume 8, Issue 4

Page Number : 355-362

Publication Issue :

July-August-2021

\section{Article History}

Accepted : 02 Aug 2021

Published: 10 Aug 2021

Rainfall is one of the vital form of precipitation which affects not only agricultural activity but also entire ecology in any region. Hence rainfall distribution and its trends in district is important to understand water availability and to take decisions for the agricultural activities in area. This research paper is an effort to assess the spatial and temporal rainfall variability of Ahmednagar district of Maharashtra State. Ahmednagar is popularly known as the largest district of Maharashtra with fourteen Talukas. The average annual rainfall of this district is $621 \mathrm{~mm}$ with an average of 46 rainy days. In this study the spatial and temporal rainfall distribution of this district is taken in to account. Short-term annual rainfall data are considered from 1998 to 2014. The daily rainfalls of monsoon months of all the fourteen Taluka are analyzed for the year 2015.It was found that spatial and temporal variability is high in the District.

Keywords : Rainfall variability, Rainy days, Cloudburst, Average rainfall, Severe Drought.
\end{abstract}

\section{INTRODUCTION}

Rainfall is considered a significant element for development of agricultural and other economic activities, rather it is treated as most fundamental factor for human development. India receives 4000 BMC of water through precipitation every year. It includes both rain and snow fall water. The rainfall is most crucial agro-climatological factor in seasonally arid part of world and its analysis is prerequisite for agricultural planning of India $[1,27,21,22,25,26$, 30]. Hence rainfall and its nature and trend at district has a great significance in water storage for future use. Maharashtra $35 \%$ of area is drought prone and it receives very scanty and very irregular rainfall. According to Sukhtankar Committee, 87 Tehsil from 12 districts having drought prone area of the state, where drought conditions are observed once in a year. Ahmednagar district is one of them [2, 31, 23, 24, 29, 28]. Rainfall in this region is uneven both in time and space. Therefore rainfall distribution in Ahmednagar district is taken in to consideration in this study. As study area comes under semi arid zone of Maharashtra. It receives erratic nature of rainfall where Rainfall variability is hampers cropping pattern in agriculture and related activities $[11,12,19,20]$. Many researchers explain stated that rainfall variability due to climate change and insufficient 
capacity to manage it, lead to poverty and food insecurity in Africa and some parts of Asia [3, 4, 13, $14,18,17]$.

\section{STUDY AREA}

So many scholars had worked on it.Alaka Gadgil and Nanbhau Kudnar and Anil Landage had work on rainfall variability. Ahmednagar district is located at central position in Maharashtra between upper Godavari and Bhima river basin $[5,6,7,15,16]$. Ahmednagar lies between $18^{0} 2$ 'to $19^{0} 9^{\prime}$ North latitude and $73^{0} 9$ 'to $75^{0} 5$ 'East longitude. Ahmednagar District is largest district of Maharashtra, District has occupy 17053sq. k.m. area which is $5.66 \%$ of states land. According to 2011 census population of district is 3372935. Ahamednagar district is characterized by Undulating hill topography and plain. Western region occupied by hill ranges and eastern area is surrounded by plains.

\section{METHODOLOGY}

Thus to fulfill above objective data has been collected from secondary sources. This data is collected from Agricultural department of Maharashtra state, Indian Meteorological Department, Pune covering the period from 1998-2014 and district Socio-economic abstract. The collected data has been processed and tabulated. Final result of statistical methods has been presented through maps and tables $[8,9,10]$.

\section{RESULTS AND DISCUSSION}

\section{A) TEMPORAL ASPECT OF RAINFALL}

Geographically Ahmednagar district of Maharashtra state has occupies Western-central location. Maharashtra $35 \%$ of area is drought prone and it receives very scanty and very irregular rainfall $[10,11$, 12]. The Sukhtankar committee, which was set up by Government of Maharashtra, has observed that 87 Tehsil from 12 districts having drought prone area of the state, where drought condition are observed once in a year. Ahmednagar district is one of them [32]. This district faces very acute problem of water scarcity. Due to its typical location it comes under rain shadow zone which reduces rainfall drastically. In temporal aspect occurrence rainfall in regards of time has been considered for study.

The average rainfall of Ahmednagar district for the last 18 years was $565 \mathrm{~mm}$. uneven distribution and uncertainty are major characteristic of rainfall in India and Ahmednagar District is no exception for it. The highest rainfall of district was recorded in the year 1998 .It was $825 \mathrm{~mm}$ and year 2003 represent as lowest rainfall year where only $325 \mathrm{~mm}$ rainfall was occurred in district. Due to rain shadow zone proximity of rainfall is very low and variability in rainfall was observed in maximum scale. The temporal aspect and characteristic can be more reveal with help of following table.it shows tehsilwise rainfall distribution in Ahmednagar district.

\section{B) SPATIAL ASPECT OF RAINFALL IN DISTRICT(2015)}

The spatial distribution of rainfall in Ahmednagar district follows orographic or relief rainfall. Spatial location of Ahmednagar district determines rainfall in district. In last 18 years spatial distribution of rainfall was observed as follows. Akole tehsil starts from Sahyadri ghatmatha therefore it receives highest rainfall (772 $\mathrm{mm})$.Jamkhed (687mm) Medium rainfall observed in Shrirampur $(559 \mathrm{~mm})$, Nagar $(576 \mathrm{~mm})$, Shevgaon $(577 \mathrm{~mm})$, Karjat $(582 \mathrm{~mm})$ tehsils. Whereas Kopargaon (454mm), Parner (483mm), Sangamner (489mm) receives lowest rainfall in district. .In the year 2015 rainfall of monsoon in Ahmednagar district was follows.

\section{CONCLUSION AND FUTURE SCOPE}

The main conclusion of study is shown in conclusion that this paper will become much useful for the farmers climatologist and the personals who study 
climatic elements and their deep study. This paper Ahmednagar district.

also become much vital for agriculturist in

Table 1 : Temporal Aspect of Rainfallin Ahmednagar District

\begin{tabular}{|c|c|c|c|c|c|c|c|c|}
\hline H & ๑ ঞ & 9 ล & ㄱํ 8 & 우 & ำ ชิ & 유 & 오 & 오 눙 \\
\hline Akola & 880 & 510 & 689 & 563 & 476 & 502 & 1354 & 1084 \\
\hline Sangamner & 575 & 472 & 658 & 438 & 492 & 489 & 650 & 529 \\
\hline Kopargaon & 667 & 551 & 451 & 368 & 337 & 341 & 479 & 406 \\
\hline Shrirampur & 828 & 332 & 575 & 542 & 308 & 259 & 553 & 550 \\
\hline Rahuri & 637 & 842 & 615 & 579 & 325 & 313 & 575 & 465 \\
\hline Newasa & 676 & 647 & 569 & 436 & 344 & 265 & 568 & 479 \\
\hline Rahata & 655 & 525 & 396 & 497 & 475 & 263 & 557 & 601 \\
\hline Nagar & 735 & 860 & 670 & 480 & 400 & 214 & 556 & 500 \\
\hline Shevgaon & 811 & 633 & 569 & 507 & 476 & 362 & 785 & 465 \\
\hline Pathardi & 1135 & 472 & 498 & 726 & 559 & 544 & 681 & 451 \\
\hline Parner & 753 & 341 & 539 & 485 & 517 & 190 & 759 & 531 \\
\hline Karjat & 964 & 629 & 468 & 686 & 525 & 328 & 635 & 606 \\
\hline Shrigonda & 951 & 768 & 402 & 620 & 421 & 110 & 574 & 484 \\
\hline Jamkhed & 1296 & 1003 & 670 & 440 & 502 & 516 & 686 & 634 \\
\hline
\end{tabular}

\begin{tabular}{|c|c|c|c|c|c|c|c|c|c|c|}
\hline 莺 & ర్రి & స్ి & ర్ & రి & 융 & 공 & ్ㅗㅇ & 뭉 & 范 & ํํํ \\
\hline Akola & 1130 & 871 & 1006 & 549 & 829 & 500 & 648 & 766 & 733 & 806 \\
\hline Sangamner & 589 & 485 & 487 & 329 & 572 & 240 & 496 & 375 & 391 & 537 \\
\hline Kopargaon & 571 & 596 & 401 & 333 & 644 & 455 & 402 & 416 & 273 & 476 \\
\hline Shrirampur & 788 & 611 & 503 & 485 & 853 & 636 & 408 & 509 & 491 & 833 \\
\hline Rahuri & 796 & 745 & 651 & 551 & 866 & 589 & 513 & 506 & 321 & 589 \\
\hline Newasa & 629 & 368 & 591 & 456 & 860 & 474 & 503 & 494 & 337 & 497 \\
\hline Rahata & 690 & 462 & 385 & 337 & 814 & 395 & 548 & 699 & 327 & 510 \\
\hline Nagar & 809 & 648 & 648 & 565 & 791 & 374 & 225 & 569 & 429 & 887 \\
\hline
\end{tabular}




\begin{tabular}{|l|l|l|l|l|l|l|l|l|l|l|}
\hline Shevgaon & 759 & 450 & 473 & 636 & 824 & 741 & 276 & 665 & 379 & 581 \\
\hline Pathardi & 804 & 443 & 625 & 617 & 932 & 616 & 250 & 608 & 414 & 631 \\
\hline Parner & 852 & 389 & 388 & 464 & 604 & 368 & 249 & 546 & 176 & 535 \\
\hline Karjat & 785 & 416 & 715 & 711 & 729 & 413 & 245 & 675 & 343 & 604 \\
\hline Shrigonda & 523 & 752 & 448 & 498 & 710 & 316 & 258 & 777 & 268 & 560 \\
\hline Jamkhed & 906 & 614 & 763 & 623 & 770 & 712 & 345 & 682 & 464. & 738 \\
\hline
\end{tabular}

Source: www.agri.mah.nic.in

Loacation, Situation and Site Map of Study Area
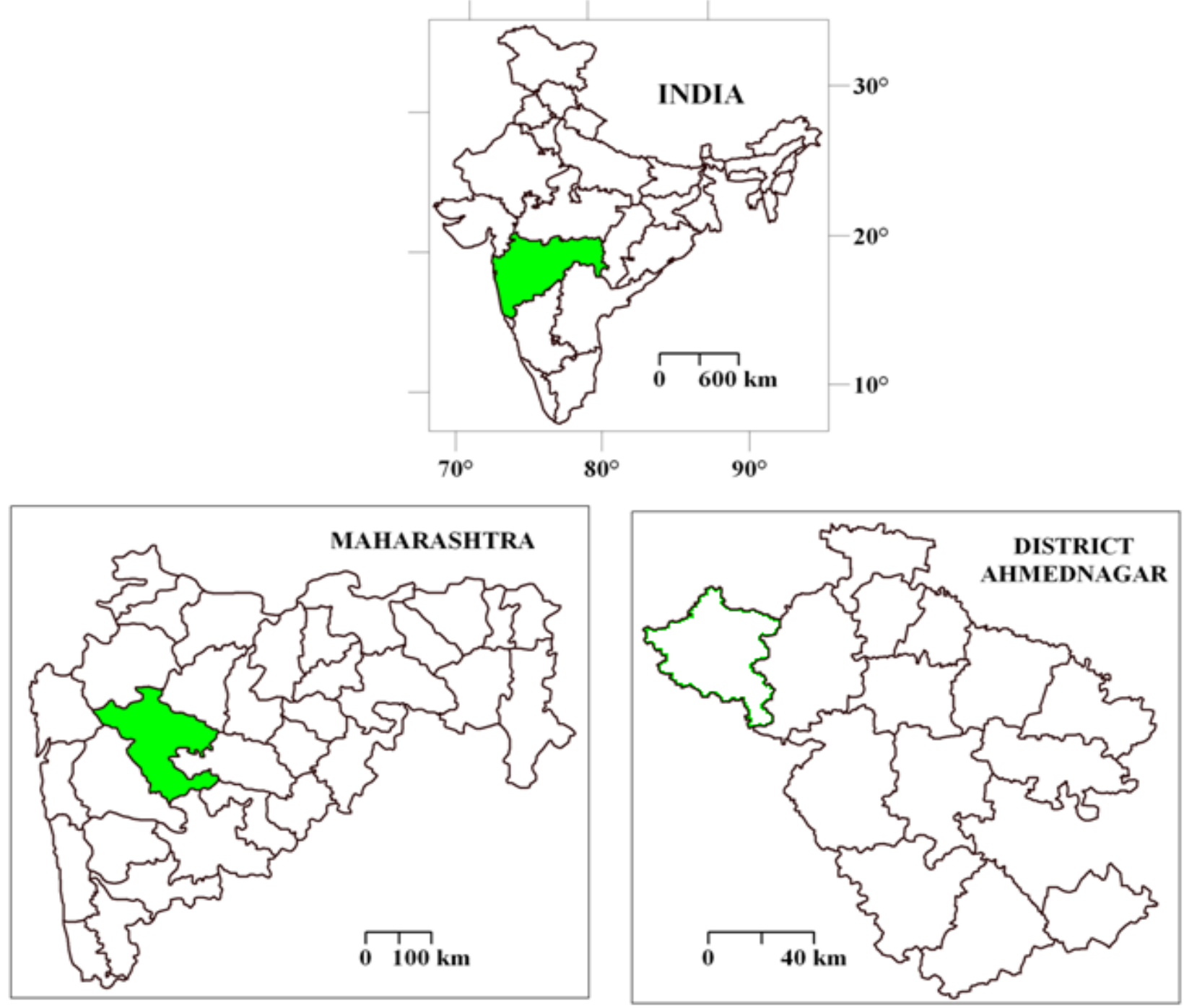

Fig.1 : Location Map of Study Area 


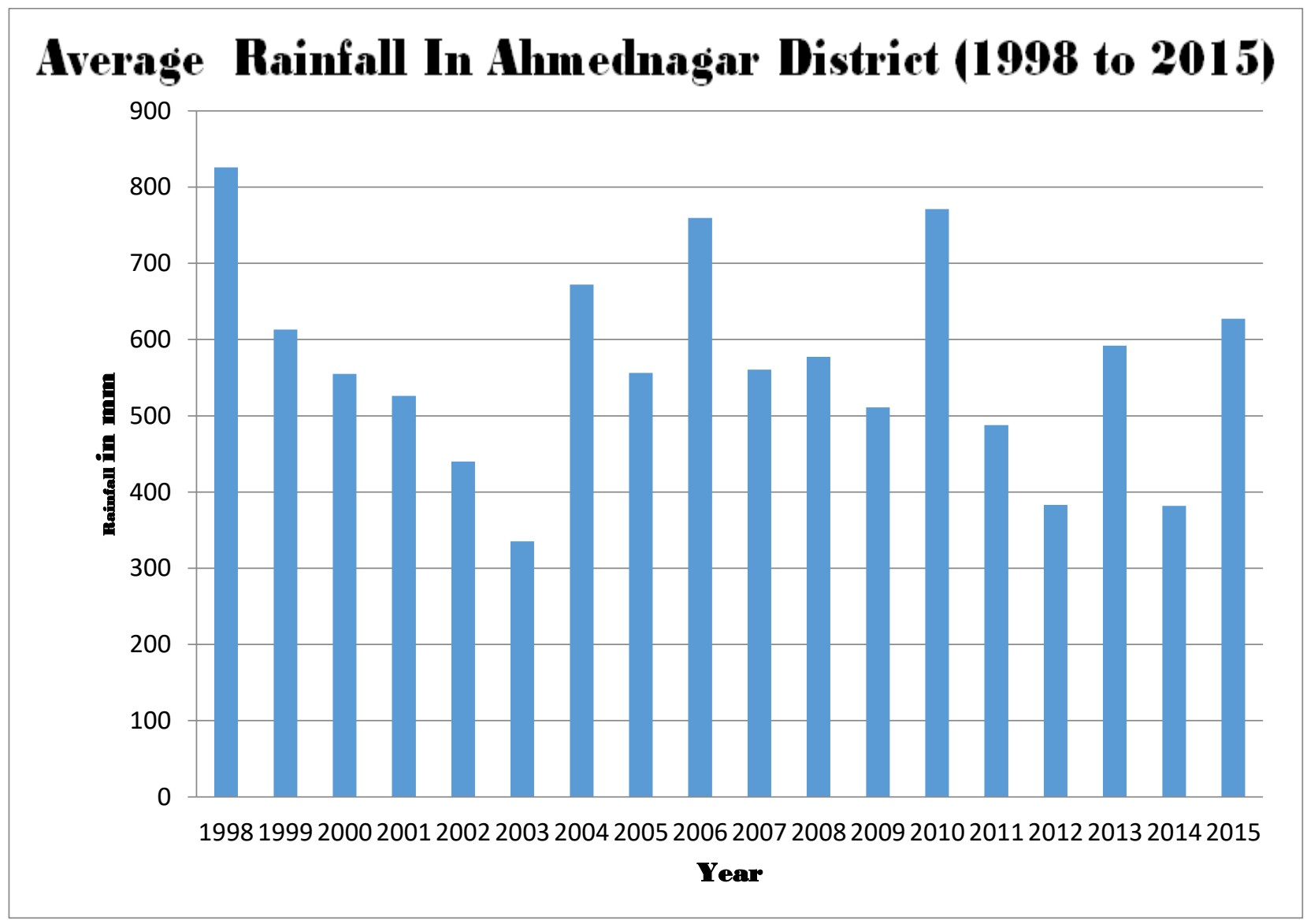

Fig. 2. Average rainfall In Ahmednagar District
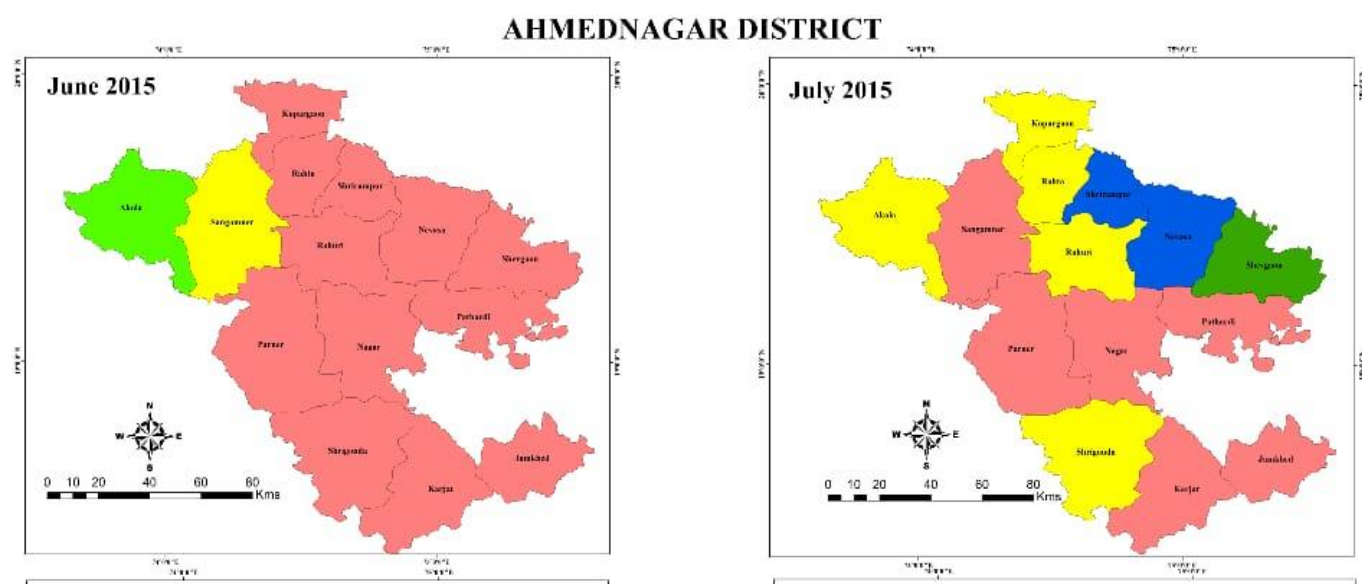

Legend

Less than $25 \%$
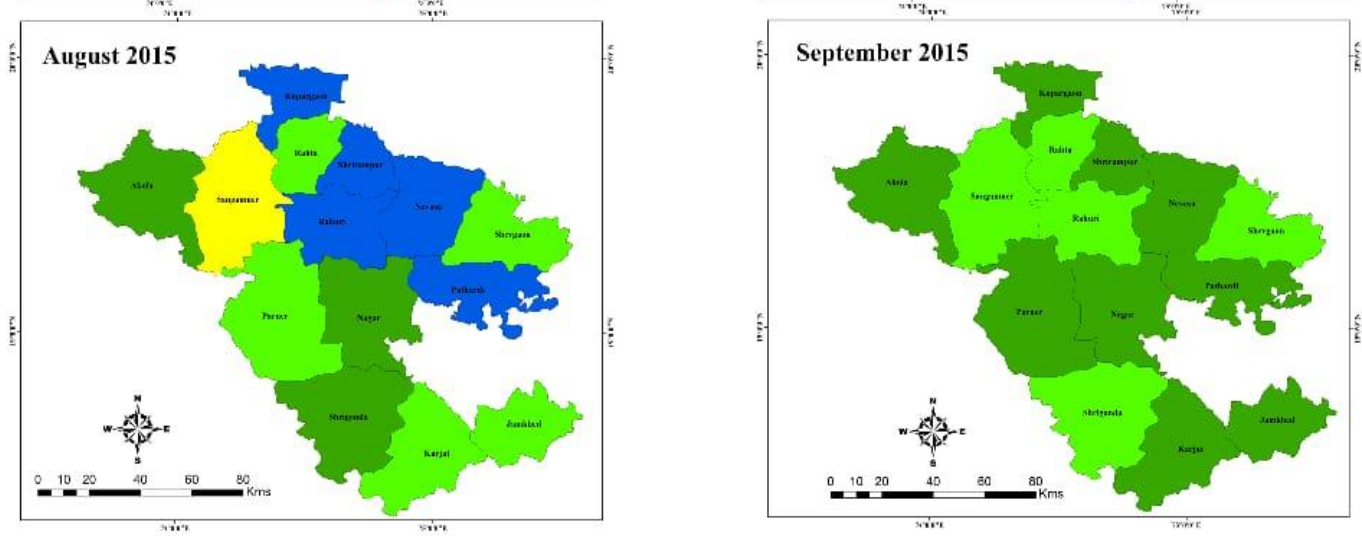

More than $99 \%$

Fig. 3. Rainfall Distribution in Ahmednagar District 


\section{CONCLUSION}

The present research paper is an efforts to appraise the spatial and temporal rainfall variability of Ahmednagar district the largest district of Maharashtra State. The district has fourteen Talukas with district headquarter at Ahmednagar. Akole Taluka of this district has natural border with Sahyadri mountain. In this study the annual rainfall from 1998-2015 is considered, high rainfall of above $565 \mathrm{~mm}$ was observed in 8 years and below $500 \mathrm{~mm}$ rainfall in 5 years. Taluka wise rainfall analysis shows that Western and southern part of the district (Three Talukas) received high rainfall and the remaining five Talukas of the district received moderate rainfall. Six Talukas get low rainfall than normal. The mean rainfall of the district in the last 18 years is $565 \mathrm{~mm}$ with a maximum of $772 \mathrm{~mm}$ rainfall in Akole Taluka and minimum of $454 \mathrm{~mm}$ in Kopargaon Taluka.

\section{REFERENCES}

[1]. Ade V.V (2019): Farmers' Suicide In Vidarbha Region of Maharashtra State: A Geo-Political View, Think India Journal, pp-12723-12732.

[2]. Bhagat R. S. (2020) GIS-Based Assessment of Physiographic and Hydrological Parameters Of Wainganga Sub Basin, Maharashtra, India. Shodh Sarita 7 (27), 14-21.

[3]. Bhagat, Ravindra and Bisen Devendra (2015) Flood Study of Wainganga River in Maharashtra Using GIS \& Remote Sensing Techniques, International Journal of Science and Research, 782-785.

[4]. Bhagat, Ravindra and Bisen Devendra (2016) Land use and Land cover of Wainganga River in Maharashtra using GIS and Remote sensing technique, Golden Research Thoughts, International Recognition Multidisciplinary Research Journal ISSN: 2231-5063, Volume - 5 | Issue -9 , Page No. 1-7
[5]. Bisen D. K. (2020) Traditional Water Management Systems of Gondia District: Community Conservation, Thematics Journal of Geography, Vol-8-Issue, 354-363.

[6]. Bisen D.K and Kudnar N.S. (2013) A Sustainable Use and Management of Water Resource of the Wainganga River Basin: - A Traditional Management Systems. figshare. Journal contribution. https: //doi.org /10.6084 /m9. figshare. 663573.v1

[7]. Bisen D.K and Kudnar N.S. (2019) Climatology, Sai Jyoti Publication, Nagpur.pp-11-211.

[8]. Cholke, S. P. (2011) "Decadal variation in Population growth of Ahmednagar District". XXXVI Maharashtra Bhugolshastra Patrika Pp 33-38.

[9]. Gadagil, A (1986) “Annual and weekly analysis of rainfall and temperature for Pune: a multiple time series approach". Inst. Indian Geographers, Vol. 8.No.1.Pp- 104-118.

[10]. Gadekar D.J, Sonkar S. (2020). Statistical Analysis of Seasonal Rainfall Variability and Characteristics in Ahmednagar District of Maharashtra, India. International Journal of Scientific Research in Science and Technology, 2395-6011, doi https://doi.org/10.32628/IJSRST207525

[11]. Gadekar D.J, Sonkar S. (2021). The Study of Physico-Chemical Characteristics of Drinking Water: A Case Study of Nimgaon Jali Village, International Advanced Research Journal in Science, Engineering and Technology, 8, 61-65.

[12]. Khullar, R. D. (2018) "India A comprehensive Geography" Kalyani Publication, Pp-391-396.

[13]. Kudnar N.S., (2017) Morphometric Analysis of the Wainganga River Basin Using Traditional \& GIS Technique, Ph.D. Thesis, Rashtrasant Tukadoji Maharaj Nagpur University, Nagpur, Pp 66-250.

[14]. Kudnar, N. S., (2015) Linear Aspects of the Wainganga River Basin Morphometry Using 
Geographical Information System Review Of Research 5 (2), 1-9

[15]. Kudnar, N.S, (2019) Impacts of GPS-based mobile application for tourism: A case study of Gondia district, Vidyawarta Int Multidiscip Res J 1:19-22.

[16]. Kudnar, N.S. and Rajasekhar, M, (2020) A study of the morphometric analysis and cycle of erosion in Waingangā Basin, India, Modeling Earth Systems and Environment 6 (1), 311-327, (2020). https://doi.org/10.1007/s40808-01900680-1

[17]. Kudnar, N.S., (2020) GIS-based assessment of morphological and hydrological parameters of Wainganga river basin, Central India. Model. Earth Syst. Environ. 6, 1933-1950. https://doi.org/10.1007/s40808-020-00804-y

[18]. Kudnar, N. S., Padole, M. S, et al (2021) "Traditional crop diversity and its conservation on-farm for sustainable agricultural production in Bhandara District, India", International Journal of Scientific Research in Science, Engineering and Technology (IJSRSET), Volume 8 Issue 1, pp. 35-43, https://doi.org/10.32628/IJSRSET207650.

[19]. Lagad S. J. (2020) Physiographic Analysis of the Hivare Bazar Village Using GIS and RS Techniques, Studies in Indian Place Names 40 (3), 5528-5536.

[20]. Lagad S. J. (2018) Demographic Development Pre and Post Watershed Development of Model Watershed Village Hivrebazar in Nagar Tahesil, International Journal of Research in Social Sciences 8 (12), 353-365.

[21]. Lagad S. J. (2019) Demographic Development Pre and Post Watershed Development of Model Watershed Village Ralegansiddhi in Parner Tahesil. Maharashtra Bhugolshastra Sanshodhan Patrika 36 (1), 37-48.

[22]. Lagad S. J. (2017) Role of Water Conservation in Rural Development- A Case Study of Model Villages in South Ahmednagar District.
Rashtrasant Tukadoji Maharaj Nagpur University, Nagpur. pp-22-300.

[23]. Lagad S.J. and Kamble D. B.(2020) Geo-Political Dispute Between India and China and Its Impact on Bilateral Trade, Studies in Indian Place Names 40 (60), 2215-2227

[24]. Rajasekhar M, Sudarsana Raju G, et al (2021) Multi-criteria Land Suitability Analysis for Agriculture in Semi-Arid Region of Kadapa District, Southern India: Geospatial Approaches, Remote Sensing of Land, 5(2), 5972. https://doi.org/10.21523/gcj1.2021050201

[25]. Salunke V. S. (2019) Study of urbanization Trends in Western Maharashtra, Maharashtra Bhugolshastra Sanshodhan patrika, 36-2, pp 6771.

[26]. Salunke V. S. (2020) Study of Talpona River Mouth by using Geospatial Technology, Studies in Indian Place Names 40 (50), 791-800.

[27]. Salunke V. S., Kudnar N. S. et al., (2020) Application of Geographic Information System (GIS) for Demographic Approach of Sex Ratio in Maharashtra State, India, International Journal for Research in Applied Science \& Engineering Technology (IJRASET), Volume 8 Issue XI, pp-259-275

[28]. Salunke V. S., Bhagat R. S. et al., (2020) Geography of Maharashtra, Prashant Publication, Jalgaon, pp- 1-229.

[29]. Salunke V. S., (2020) Geographical analysis of scheduled tribe's population in Ahmednagar district, Maharashtra Bhugolshastra Sanshodhan Patrika 37 (1), 52-56.

[30]. Salunke V.S, Lagad S.J et al. 2021. "A Geospatial Approach to Enhance Point of the Interest and Tourism Potential Centers in Parner Tehsil in Maharashtra, India", International Journal of Scientific Research in Science, Engineering and Technology (IJSRSET),Volume 8 Issue 1, pp. 186-196, https://doi.org/10.32628/IJSRSET218136 
[31]. Todmal R. S. (2020). Understanding the hydrometeorological characteristics and relationships in the semiarid region of Maharashtra (western India): implications for water management. Acta Geophys. 68, 189-206. https://doi.org/10.1007/s11600-019-00386-z

[32]. Tripathi, S.K. (2009) "Rainfall Analysis for Cropping Planning: A Lesson from Uttarakhand",Journal of Applied Hydrology, Vol XXII No.I, Jan2009, Pp 42-54.

\section{Cite this article as :}

Dr. Vasudev S. Salunke, Pramila. P. Zaware, "Rainfall Characteristics in Ahmednagar District of Maharashtra State", International Journal of Scientific Research in Science, Engineering and Technology (IJSRSET), Online ISSN : 2394-4099, Print ISSN : 2395-1990, Volume 8 Issue 4, pp. 355-362, JulyAugust 2021. Available at doi : https://doi.org/10.32628/IJSRSET218447 Journal URL : https://ijsrset.com/IJSRSET218447

\section{AUTHORS PROFILE}

1.Pramila Zaware is Research Scholoar and perusing her Ph.D.

2.Dr.V.S.Salunke. pursed M.A. B.Ed., NET in Geography and Ph.D. in Geography from S.P.Pune University, in 2005, 2006 \& 2015 respectively. He is currently working as Assistant Professor in Department of Geography from K.J.Somaiya College, Kopargaon since 2007. He is a, Life member of MBP since 201. He has published more than 21 research papers in reputed international journals including Thomson Reuters (SCI \& Web of Science) and conferences including and it's also available online. He has 14 years of teaching experience and 6 years of research experience. 